\title{
Tick-host conflict: immunoglobulin E antibodies to tick proteins in patients with anaphylaxis to tick bite
}

\author{
Lourdes Mateos-Hernández ${ }^{1}$, Margarita Villar ${ }^{1}$, Angel Moral ${ }^{2}$, Carmen García \\ Rodríguez $^{3}$, Teresa Alfaya Arias ${ }^{3}$, Verónica de la Osa ${ }^{2}$, Francisco Feo Brito ${ }^{3}$, Isabel \\ G. Fernández de Mera ${ }^{1}$, Pilar Alberdi ${ }^{1}$, Francisco Ruiz-Fons ${ }^{1}$, Alejandro Cabezas- \\ Cruz $^{4,5}$, Agustín Estrada-Peña ${ }^{6}$ and José de la Fuente ${ }^{1,7}$ \\ ${ }^{1}$ SaBio, Instituto de Investigación de Recursos Cinegéticos, IREC-CSIC-UCLM-JCCM, Ciudad Real, Spain \\ 2 Department of Allergy, Hospital Virgen del Valle, Toledo, Spain \\ ${ }^{3}$ Allergy Section, General University Hospital of Ciudad Real, Ciudad Real, Spain \\ ${ }^{4}$ Institute of Parasitology, Biology Center of the Academy of Sciences of The Czech Republic, České Budějovice, Czech \\ Republic \\ ${ }^{5}$ Faculty of Science, University of South Bohemia, České Budějovice, Czech Republic \\ ${ }^{6}$ Department of Animal Pathology, Faculty of Veterinary Medicine, University of Zaragoza, Miguel Servet, Zaragoza, Spain \\ 7 Department of Veterinary Pathobiology, Center for Veterinary Health Sciences, Oklahoma State University, Stillwater, \\ Oklahoma, USA \\ Correspondence to: José de la Fuente, email: jose_delafuente@yahoo.com \\ Keywords: immunology, allergy, alpha-Gal, anaphylaxis, proteomics, Immunology and Microbiology Section, Immune response, \\ Immunity \\ Received: November 07, $2016 \quad$ Accepted: January 28, $2017 \quad$ Published: February 09, 2017
}

\section{ABSTRACT}

Tick-borne infectious diseases and allergies are a growing problem worldwide. Tick bite allergy has been associated with the direct effect of immunoglobulin E (IgE) response to tick salivary antigens, or secondary to the induction of allergy to red meat consumption through IgE antibodies against the carbohydrate a-Gal (Gal a 1-3Gal $\beta$ 1-(3)4GIcNAC-R). However, despite the growing burden of this pathology, the proteins associated with anaphylaxis to tick bite have not been characterized. To address this question, a comparative proteomics approach was used to characterize tick proteins producing an IgE antibody response in a healthy individual with record of tick bites, which had not resulted in any allergic reactions, and two patients with anaphylactic reactions to Rhipicephalus bursa or Hyalomma marginatum tick bites. Both patients and the healthy individual were red meat tolerant. The results supported a patientspecific IgE antibody response to tick species responsible for the anaphylaxis to tick bite. Both patients and the healthy individual serologically recognized tick proteins with and without a-Gal modifications, with proteins differentially recognized by patients but not control sera. These proteins could be used as potential antigens for diagnostics, treatment and prevention of tick bite-induced allergies.

\section{INTRODUCTION}

Ticks are blood-sucking ectoparasites that feed on different vertebrate hosts to complete their life cycle [1]. Humans are accidental hosts, but tick-borne diseases are a growing problem worldwide $[2,3]$. Tick modulate host immunity through salivary gland proteins that are injected into the host during blood feeding to suppress inflammatory responses and facilitate feeding and pathogen transmission $[4,5]$.

The first case of anaphylaxis, secondary to allergy to tick bite was reported in Australia in 1940 [6]. Although this problem remains most prominent in Australia, where fatality cases have been recorded [7], anaphylaxis to tick bite has been also reported in the United States and Europe $[8,9]$. The morbidity associated with tick bite allergy has been associated with the direct effect of immunoglobulin E (IgE) response to tick salivary antigens [7-10], or secondary to the induction of allergy to red meat consumption through $\operatorname{IgE}$ antibodies against the carbohydrate $\alpha$-Gal (Gal $\alpha$ 1-3Gal $\beta$ 1-(3)4GlcNAc-R) [11-20]. Humans do not synthesize $\alpha$-Gal and healthy individuals develop a potent immune response against this carbohydrate widely present on tissues of nonprimate 
mammals [21, 22]. Recently, van Nunen et al. [17] reported that patients living in a tick endemic region of Australia developed red meat allergy after experiencing large local reactions to tick bites. This finding led to the suggestion that tick-induced allergies to red meat and other compounds may occur after anaphylactic reactions to tick bite [23].

The anaphylaxis to tick bite has been associated with a variety of both soft- and hard-bodied tick species $[8-10,24]$. However, despite the growing burden of this pathology worldwide [7], the proteins associated with anaphylaxis to tick bite have not been characterized. To address this question, the goal of this study was to use a comparative proteomics approach to characterize tick proteins producing an antibody response in a healthy individual with record of tick bites, which had not resulted in any allergic reactions, and two patients with anaphylactic reactions to Rhipicephalus bursa or Hyalomma marginatum tick bites. Both patients and the healthy individual were red meat tolerant. The results suggested proteins that could be used as potential antigens for the diagnostics, treatment and prevention of tick biteinduced allergies.

\section{RESULTS}

\section{Diagnosis of patients with immediate anaphylaxis to tick bite but without delayed anaphylaxis to mammalian red meat}

Two unrelated adult male patients diagnosed with immediate anaphylaxis to $R$. bursa (patient 1; Figures $1 \mathrm{~A}$ and $1 \mathrm{~B}$ ) or $H$. marginatum (patient 2) tick bite, but without delayed anaphylaxis to red meat consumption were selected for the study. An unrelated adult male with record of tick bites, which had not resulted in any allergic reactions, was also included in the study as a healthy control individual. Skin prick tests to commercial food allergens from pork, horse, lamb, rabbit, ostrich meats, beef and bovine serum albumin (BSA) were negative
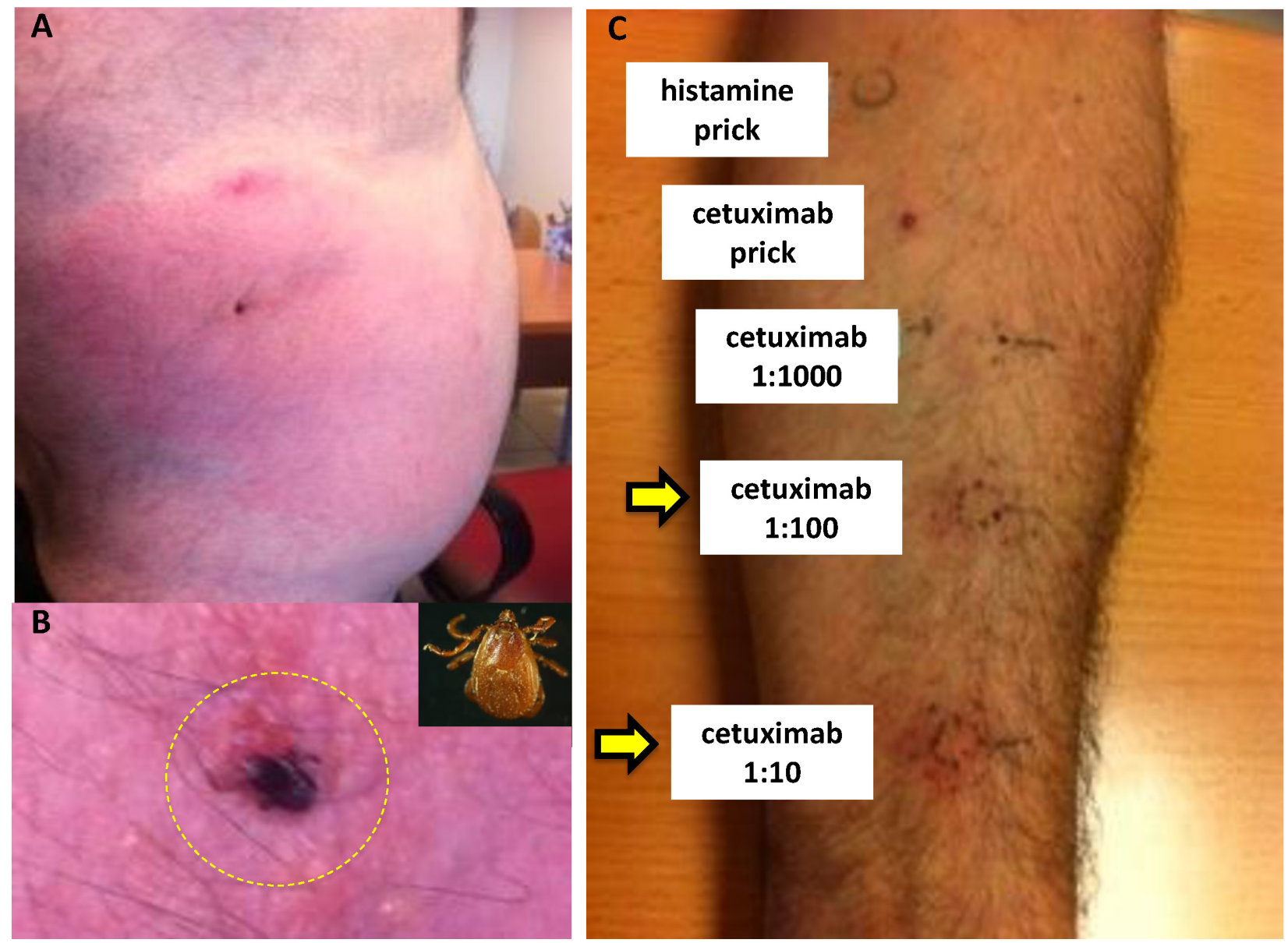

Figure 1: Case presentation for patient 1. A. The anaphylactic reaction was diagnosed in patient 1 after $R$. bursa tick bite that resulted in generalized itching, difficult breathing, nausea and somnolence that required medical attention. B. Female $R$. bursa attached to patient's skin and shown in more detail in the inset. C. Patient's positive intradermal reaction to cetuximab (1:100 to 1:10 dilution; arrows). Intradermal reaction to cetuximab (1:1000 dilution) and to cetuximab prick were negative. Histamine prick was used as positive skin test control. 
Table 1: Tick proteins differentially recognized by IgE in patients but not healthy individual control sera and reacting or not with anti- $\alpha$-Gal antibodies

\begin{tabular}{|c|c|c|c|}
\hline \multirow{2}{*}{ Accession No. } & \multirow{2}{*}{ Description } & \multicolumn{2}{|c|}{ Reactive against serum } \\
\hline & & Patients & Anti-a-Gal \\
\hline \multicolumn{4}{|c|}{ Patient 1 (R. microplus BME/CTVM23 cell proteins) } \\
\hline A0A034WWU3 & Alpha2 macroglobulin 2 & + & + \\
\hline A0A034WXE0 & Heat shock protein 701 & + & + \\
\hline A0A034WXL0 & Heat shock protein 901 & + & + \\
\hline A0A034WXY9 & Heat shock protein 70 cognate & + & + \\
\hline A0A034WYY9 & Elongation factor 1-alpha & + & - \\
\hline A0A034WZ70 & Alpha tubulin 1 & + & + \\
\hline L7LU17 & $\begin{array}{l}\text { Putative hydroxyacyl-coenzyme a dehydrogenase/3-ketoacyl- } \\
\text { coenzyme a thiolase/enoyl-coenzyme a hydrat }\end{array}$ & + & + \\
\hline L7LUC2 & Adenylyl cyclase-associated protein & + & + \\
\hline L7LVV5 & Putative klingon & + & + \\
\hline L7LW52 & Isocitrate dehydrogenase [NADP] & + & - \\
\hline L7LX08 & $\begin{array}{l}\begin{array}{l}\text { Putative molecular chaperones mortalin/pbp74/grp75 hsp70 } \\
\text { superfamily }\end{array} \\
\end{array}$ & + & + \\
\hline L7M2Y0 & Putative igf-ii mrna-binding protein imp & + & + \\
\hline L7M4I4 & Putative nucleotide excision repair factor nef $2 \operatorname{rad} 23$ component & + & - \\
\hline L7M612 & Putative ubiquitin regulatory protein & + & + \\
\hline L7M755 & Putative nadh-ubiquinone oxidoreductase ndufs $1 / 75 \mathrm{kDa}$ subunit & + & + \\
\hline L7M782 & Putative vacuolar $\mathrm{h}+$-atpase v1 sector subunit $\mathrm{b}$ & + & - \\
\hline L7M817 & Putative peptid & + & - \\
\hline L7M875 & Tubulin beta chain & + & + \\
\hline L7M8B5 & Putative spliceome rna helicase ddx39b & + & - \\
\hline L7M8Z1 & Putative dynamitin & + & - \\
\hline L7MAA0 & ATP synthase subunit alpha & + & + \\
\hline L7MAE4 & Putative chaperonin protein & + & + \\
\hline L7MAG2 & Fascin & + & + \\
\hline L7MAL5 & Uncharacterized protein & + & + \\
\hline L7MAR2 & Putative thioredoxin/protein disulfide isomerase & + & + \\
\hline L7MAS7 & Putative tubulin beta $2 \mathrm{~b}$ class iib & + & - \\
\hline L7MAT5 & Succinyl-CoA ligase subunit beta & + & - \\
\hline L7MAX7 & Putative eukaryotic translation initiation factor $4 \mathrm{a} 2$ & + & - \\
\hline L7MBL7 & Putative pleckstrin logy domain-containing family f member 2 & + & - \\
\hline L7MD56 & Putative neural cell adhesion molecule 11 & + & - \\
\hline L7MDQ8 & ATP synthase subunit beta & + & - \\
\hline L7MEG0 & Putative heat shock protein & + & + \\
\hline L7MHM2 & Uncharacterized protein & + & - \\
\hline L7MIL3 & Putative aldehyde dehydrogenase & + & + \\
\hline L7MJP7 & Putative serine/threonine protein kinase gpbp & + & + \\
\hline Q7YW74 & Cathepsin L-like cysteine proteinase B & + & - \\
\hline \multicolumn{4}{|c|}{ Patient 2 (H. marginatum salivary gland proteins) } \\
\hline A0A131XJ07 & Putative alternative splicing factor & + & - \\
\hline E2J6Q7 & Putative cement protein & + & - \\
\hline
\end{tabular}

in both patients, in correspondence with the absence of reports of allergic reactions to read meat consumption. The IgE levels to commercial allergens including pork, lamb, rabbit and BSA were also negative $(<0.35 \mathrm{kU} / \mathrm{l})$. However, patient 1 but not patient 2 had a positive intradermal reaction to cetuximab (1:100 to $1: 10$ dilution; Figure $1 \mathrm{C}$ ). The total $\mathrm{IgE}$ content and response to $\alpha$-Gal determined using the ImmunoCAP Phadia kits were higher in patient $1(128.0 \mathrm{kU} / 1$ and $3.5 \mathrm{kU} / 1$, respectively) than in patient $2(51.2 \mathrm{kU} / 1$ and $0.01 \mathrm{kU} / \mathrm{l})$ and healthy control 
individual (23.3 kU/1 and $0.02 \mathrm{kU} / \mathrm{l})$. Furthermore, the anti- $\alpha-$ Gal $\operatorname{IgE}$ and $\operatorname{IgG}$ antibody titers determined by ELISA were also higher in patient 1 than in patient 2 and the healthy individual (Figure 2A).

The analysis of serum samples identified IgE, IgM and IgG antibodies against $R$. bursa and $H$. marginatum salivary gland, and Rhipicephalus microplus BME/ CTVM23 cell proteins in both patients and control individual (Figures 2B-2D). In general, the antibody levels against tick salivary gland proteins were higher in patients than in control individual (Figures 2B and 2C). However, the antibody levels against $R$. microplus cell proteins tend to be lower in patient 1 than in patient 2 and healthy control (Figure 2D).

These results supported the diagnosis of anaphylaxis to tick bite in patients 1 and 2, and suggested the possible implication of anti- $\alpha$-Gal IgE response in patient 1 but not in patient 2 . However, the immediate anaphylaxis after tick bite in patients 1 and 2 appeared not to be related to red meat consumption, and both patients continue consuming red meat without any allergic reactions. Furthermore, no correlation was found between $\mathrm{IgE}$, IgM or IgG antibody levels to tick proteins and $\alpha-\mathrm{Gal}$ in both patients and the healthy individual (Figure 3A). The antibody response was characterized using similar methods, therefore suggesting that the absence of correlation between the antibody levels to tick proteins and $\alpha$-Gal reflects a differential response to these antigens.

Identification and characterization of tick proteins recognized by patient and healthy individual control sera and reactive with anti- $\alpha$ Gal antibodies

To identify tick proteins that react with patient and control sera, and potentially containing $\alpha$-Gal, $R$. bursa and $H$. marginatum salivary gland and $R$. microplus BME/CTVM23 tick cell proteins were analyzed by onedimensional (1-D) and two-dimensional (2-D) Western blot using patient and control sera, and anti- $\alpha-G a l$ antibodies (Figures 3B-5).

First, a 1-D Western blot was used to characterize the $\operatorname{IgE}$ antibody response to tick proteins in patients 1 and 2 (Figure 3B). The results showed a protein recognition pattern with patient 1 serum against $R$. bursa salivary
A

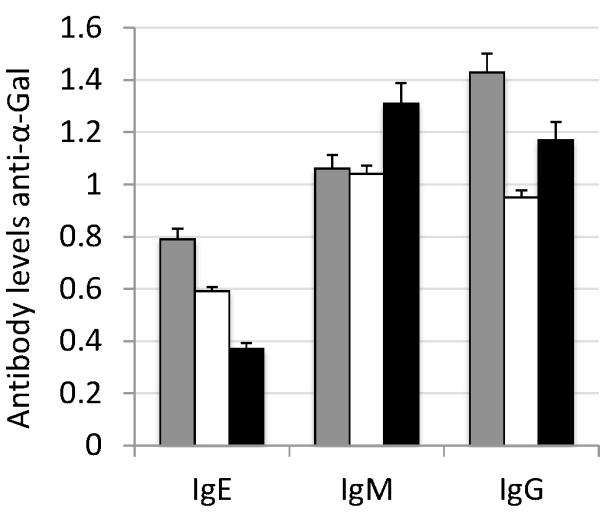

C

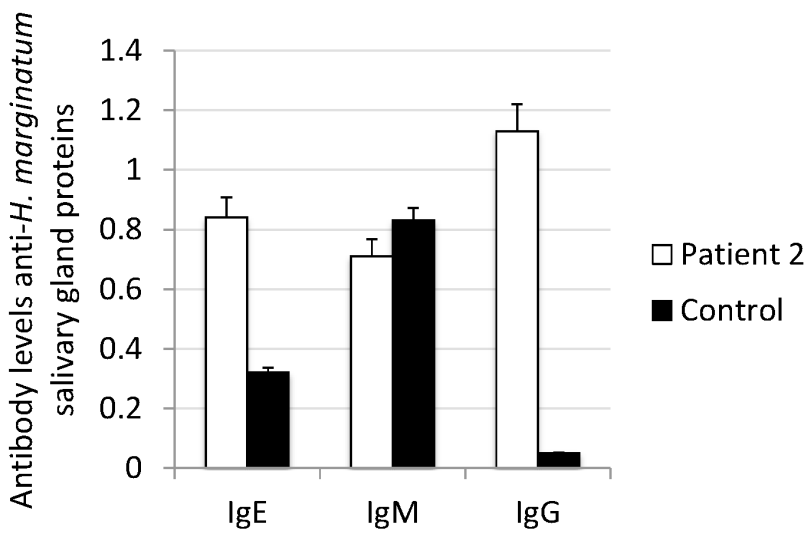

B

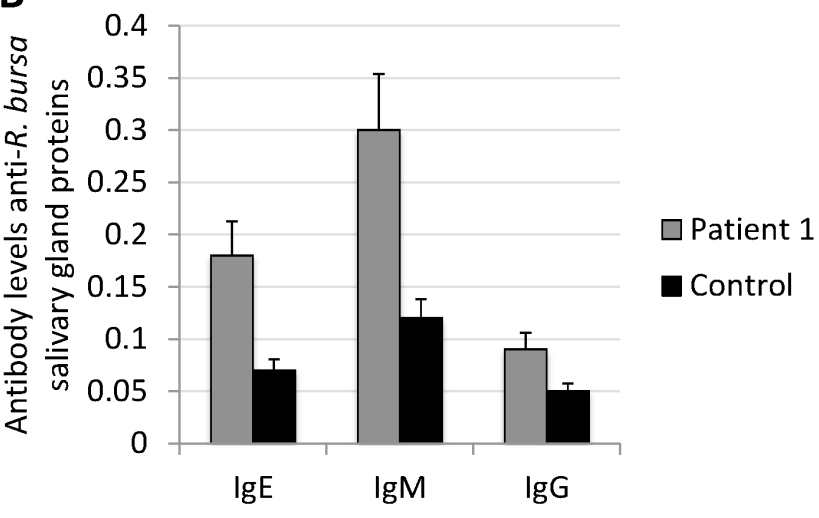

D

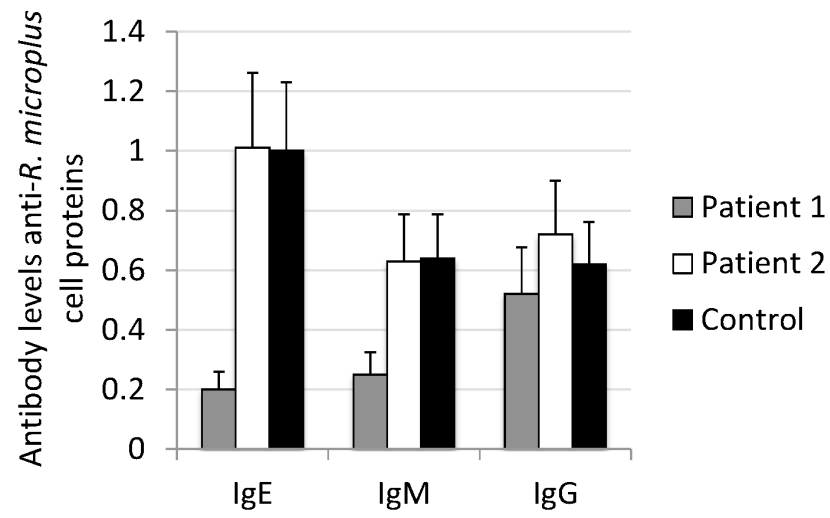

Figure 2: Immunological response to tick proteins. The IgE, IgM and IgG antibody levels were determined by ELISA in patients and control serum samples against A. $\alpha$-Gal, B. $R$. bursa salivary gland proteins, C. H. marginatum salivary gland proteins, and D. $R$. microplus BME/CTVM23 tick cell proteins. Antibody levels were determined as OD at $450 \mathrm{~nm}$ and shown as average $+\mathrm{SD}$ of 4 technical replicates. 
glands and $R$. microplus tick cell proteins (Figure 3B). However, patient 2 serum reacted against $H$. marginatum salivary gland proteins but not against $R$. microplus tick cell proteins (Figure 3B). These results agreed with the ELISA results showing that both patients have antibodies against tick proteins (Figures $2 \mathrm{~B}$ and $2 \mathrm{C}$ ), but suggested a patient-specific antibody response to tick species responsible for the reported anaphylactic reaction to tick bite (i.e. Rhipicephalus spp. in patient 1 and $H$. marginatum in patient 2).
The R. microplus BME/CTVM23 tick cells and $H$. marginatum salivary gland proteins were then used for higher resolution 2-D gel Western blots and mass spectrometry (MS) to identify proteins differentially recognized by $\operatorname{IgE}$ in patients but not control sera and reacting with anti- $\alpha-$ Gal antibodies (Figures 4 and 5). A total of 139 R. microplus BME/CTVM23 tick cell proteins were identified from the 20 spots recognized by patient 1 or control sera and by anti- $\alpha-$ Gal antibodies in the 2-D gels (Figure 4 and Supporting information Data Set 1). As

A
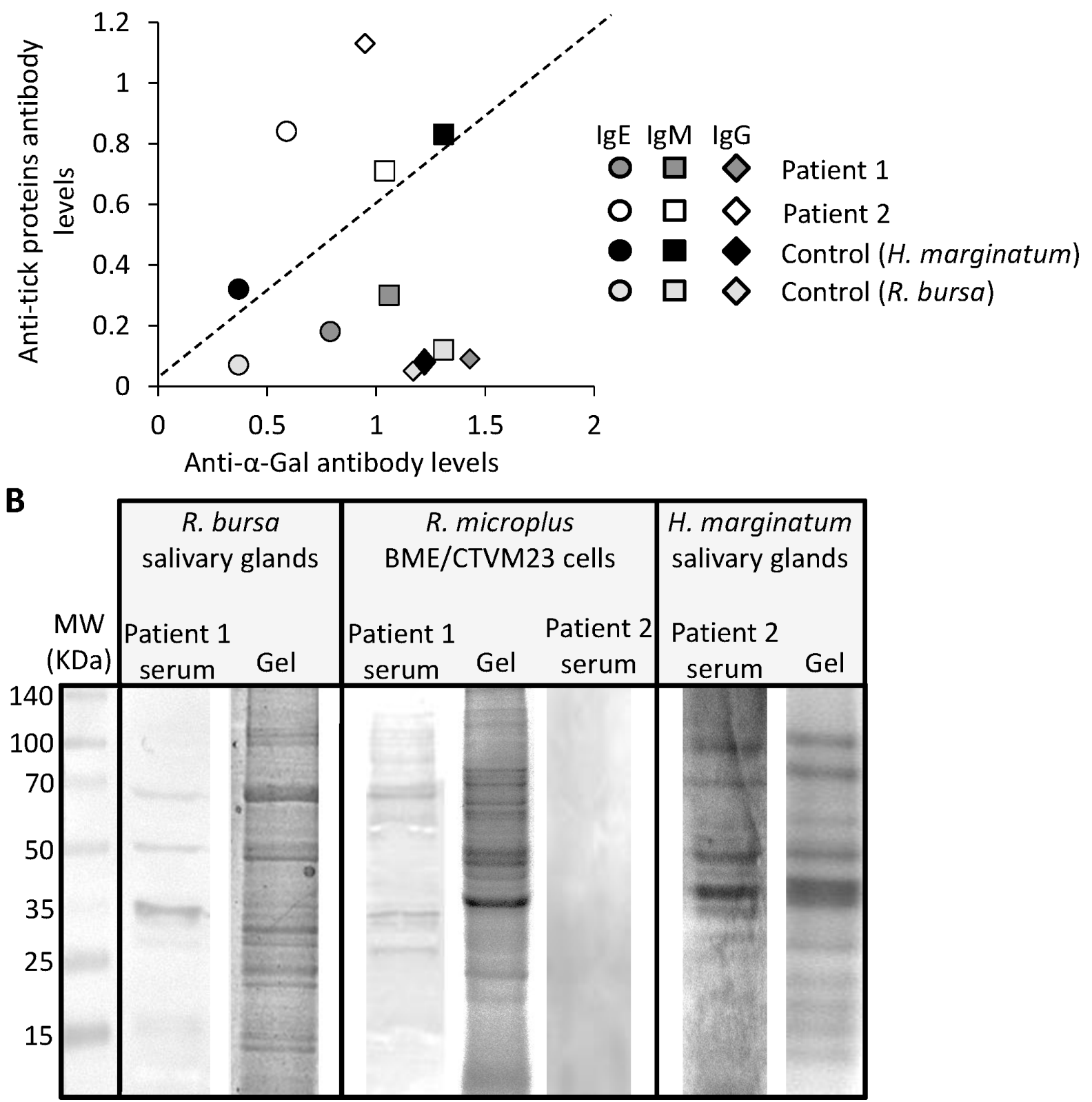

Figure 3: Patient-specific antibody response to tick species responsible for the reported anaphylactic reaction to tick bite. A. Correlation analysis between $\operatorname{IgE}, \operatorname{IgM}$ and $\operatorname{IgG}$ antibody levels against $R$. bursa or $H$. marginatum tick proteins and $\alpha-G a l$ in patients 1 and 2 and healthy control individual. Antibody levels were determined as OD at $450 \mathrm{~nm}$ and shown as the average of 4 technical replicates. B. The IgE response to $R$. bursa and H. marginatum salivary gland and $R$. microplus BME/CTVM23 tick cell proteins was analyzed by 1-D Western blot using patient 1 and 2 sera. Abbreviation: MW, molecular weight protein marker. 
in the 1-D Western blot analysis (Figure 3B), no proteins were recognized by patient 2 serum (Figure 4 ). Of the identified proteins, 70 were unique (not repeated between protein spots) (Supporting information Data Set 1). These unique proteins had a high representation in enzymatic activity and binding molecular functions, accounting for $87 \%$ of all proteins (Figure $6 \mathrm{~A}$ ), and in metabolic process, protein folding and proteolysis biological processes, accounting for $41 \%$ of all proteins (Figure 6B). Thirty-one proteins were identified in spots positive for $\alpha$-Gal (Figure 4 and Supporting information Data Set 1), with similar representation for molecular function (Figure 6C) and biological process (Figure 6D) ontology to all identified proteins (Figures 6A and 6B). Of the 70 identified unique proteins, only 29 had cellular component assignments with a prevalent localization in the cytoplasm $(14 / 29 ; 48 \%)$ (Supporting information Data Set 1). However, of the 70 unique proteins identified in R. microplus BME/CTVM23 tick cells, 65 (93\%) had orthologs in the sialome reported in other tick species (Supporting information Data Set 1), suggesting that these proteins may be present in tick saliva.

In $H$. marginatum salivary gland proteins, a total of 32 proteins were identified from the 14 spots recognized by patient 2 or control sera and by anti- $\alpha$-Gal antibodies in the 2-D gels (Figure 5 and Supporting information Data Set 1). Supporting the patient-specific antibody response to tick species responsible for the reported anaphylactic reaction to tick bite, patient 1 serum did not recognize $H$. marginatum proteins (Figure 5). Of the identified proteins, 28 were unique (not repeated between protein spots) (Supporting information Data Set 1). As in $R$. microplus cell proteins, enzymatic activity and binding were the most represented molecular functions, accounting for $51 \%$ of all proteins (Figure 7A). However, for biological process ontology differences were observed
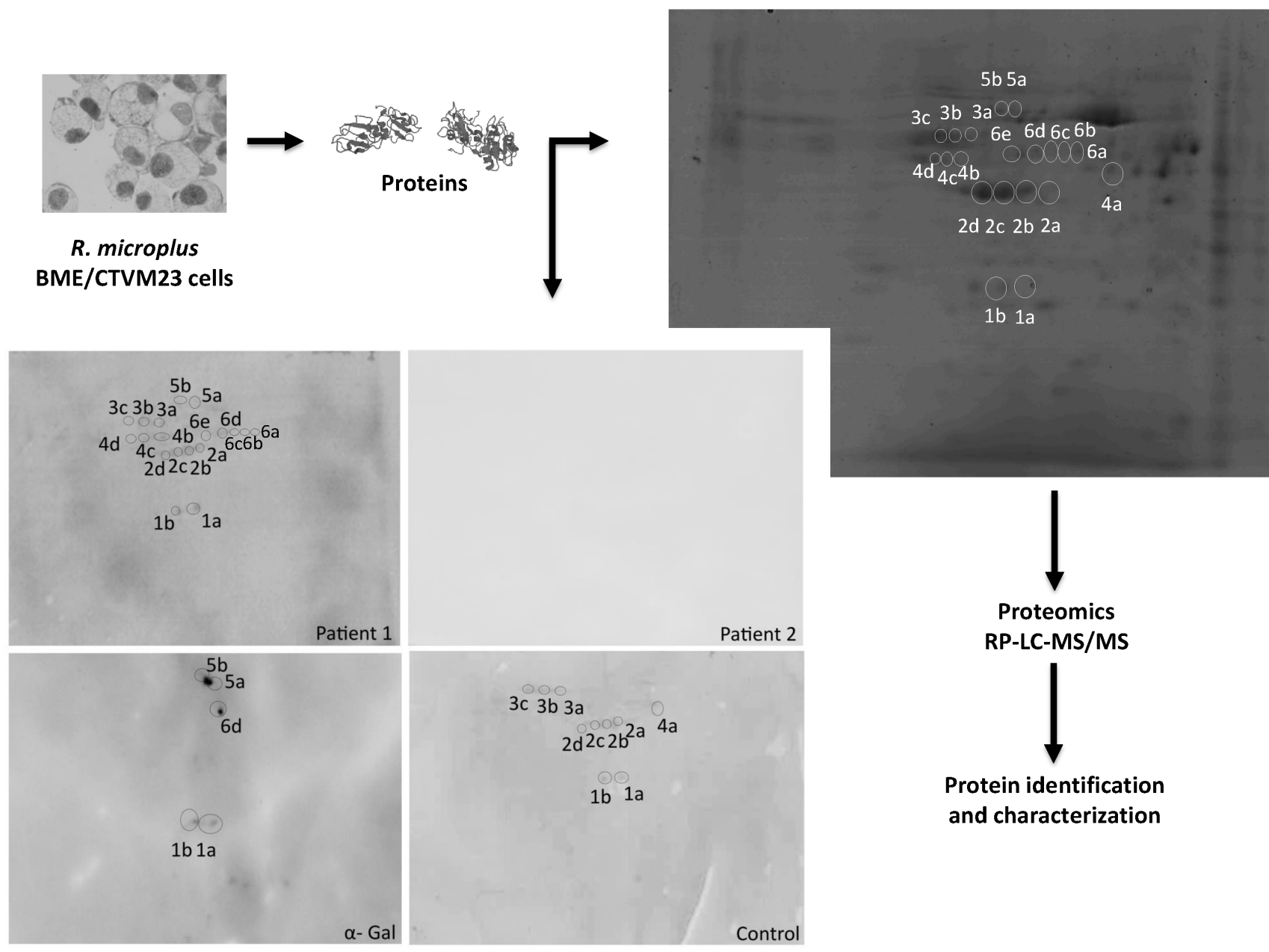

Figure 4: Rhipicephalus tick proteins recognized by IgE in patient 1 and control sera and by anti- $\alpha-G a l$ IgE antibodies. The R. microplus BME/CTVM23 tick cell proteins were extracted and analyzed by 2-D Western blot using patients and control sera and anti- $\alpha$-Gal antibodies. The protein spots of interest recognized by patients or control sera and by anti- $\alpha$-Gal antibodies were manually excised from the stained gel and used for proteomics analysis. The same settings were used for all four panels in which proteins were resolved by isoelectrical focusing at $\mathrm{pH}$ 3-11 followed by $12 \%$ SDS gel electrophoresis in the second dimension with 140-15 $\mathrm{kDa}$ molecular weight range. 
between $R$. microplus cells and $H$. marginatum salivary gland proteins, in which $51 \%$ of the proteins could not be assigned to a biological process (Figure 7B). For example, although protein folding was present in both datasets (Figures 6B and 7B), translation and glycolytic processes were better represented in $H$. marginatum than in $R$. microplus proteins. Nevertheless, protein processing in general was highly represented in both $R$. microplus and $H$. marginatum identified unique proteins (Figures 6B and 7B). Six proteins were identified in spots positive for $\alpha$-Gal (Figure 5 and Supporting information Data Set 1), and as in R. microplus proteins (Figures 6A and $6 \mathrm{C}$ ), showed a similar representation for molecular function (Figure 7C) than for all identified unique proteins (Figure 7A). For the biological process ontology of proteins identified in spots positive for $\alpha$-Gal (Figure 7D), the most represented processes such as cytoskeleton organization, ATP synthesis/hydrolysis, proton transport, glycolytic process, cell migration, muscle contraction, and embryonic development accounting for $90 \%$ of all proteins were also represented in all H. marginatum (Figure 7B) and $R$. microplus (Figures 6B and 6D) identified unique proteins. As in R. microplus cells, most of the 28 unique proteins identified in $H$. marginatum salivary glands with cellular component assignments were cytoplasmic and intracellular (9/12; 75\%) (Supporting information Data Set 1). However, as expected for salivary gland proteins, $96 \%$ of the 28 unique proteins identified in $H$. marginatum had orthologs in the sialome reported in other tick species (Supporting information Data Set 1), supporting that these proteins are present in tick saliva.

These results supported a patient-specific antibody response to tick species responsible for the reported anaphylactic reaction to tick bite. The tick proteins recognized by patient and control sera showed a high representation in the enzymatic activity and binding

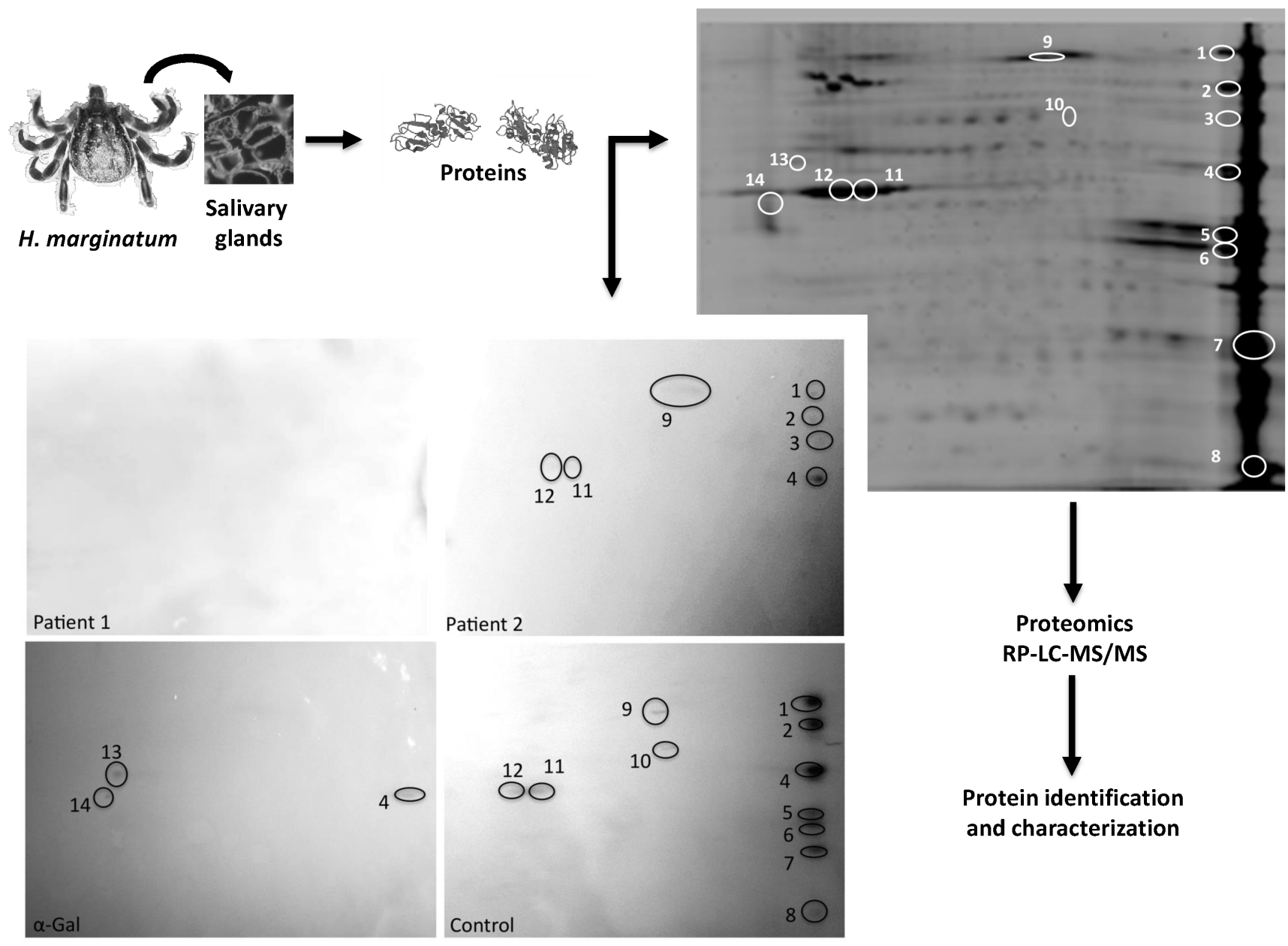

Figure 5: Hyalomma tick proteins recognized by IgE in patient 2 and control sera and by anti- $\alpha$-Gal IgE antibodies. The $H$. marginatum salivary glands were dissected and proteins were extracted and analyzed by 2-D Western blot using patients control sera and anti- $\alpha$-Gal antibodies. The protein spots of interest recognized by patient or control sera and by anti- $\alpha$-Gal antibodies were manually excised from the stained gel and used for proteomics analysis. The same settings were used for all four panels in which proteins were resolved by isoelectrical focusing at $\mathrm{pH}$ 3-11 followed by 12\% SDS gel electrophoresis in the second dimension with 140-15 kDa molecular weight range. 
molecular functions, and in protein processing biological process. Most of the identified proteins were present in the sialome reported in other tick species, supporting that these proteins are or may be present in tick saliva and therefore secreted to the host during tick feeding. Finally, some of the tick proteins were identified in spots positive for $\alpha$-Gal, suggesting the presence of this posttranslational modification in some of these proteins.

\section{Identification and characterization of tick proteins differentially recognized by patient but not healthy individual control sera}

Tick proteins that react with $\operatorname{IgE}$ in patients but not control sera were identified and characterized as a potential source for the development of anaphylactic reactions to tick bite. In $R$. microplus tick cells, 61 proteins ( 35 unique) were recognized by patient 1 serum only, of which 31 proteins (21 unique) were positive for $\alpha$-Gal (Table 1 and Supporting information Data Set 1). Five unique proteins were recognized by control serum only, while 73 proteins (38 unique) were positive against both patient 1 and control sera (Supporting information Data Set 1). In $H$. marginatum salivary glands, only two unique proteins were cognized by patient 2 but not control sera and were not positive for $\alpha$-Gal (Table 1 and Supporting information Data Set 1). Sixteen unique proteins were recognized by control serum, and none of them were positive for $\alpha$-Gal (Supporting information Data Set 1). Tick proteins differentially recognized by IgE in patients sera and positive for $\alpha$-Gal could not be grouped by common molecular function or biological process categories (Table 1), suggesting that the role of these proteins in developing anaphylaxis to tick bite may not be related to protein function.
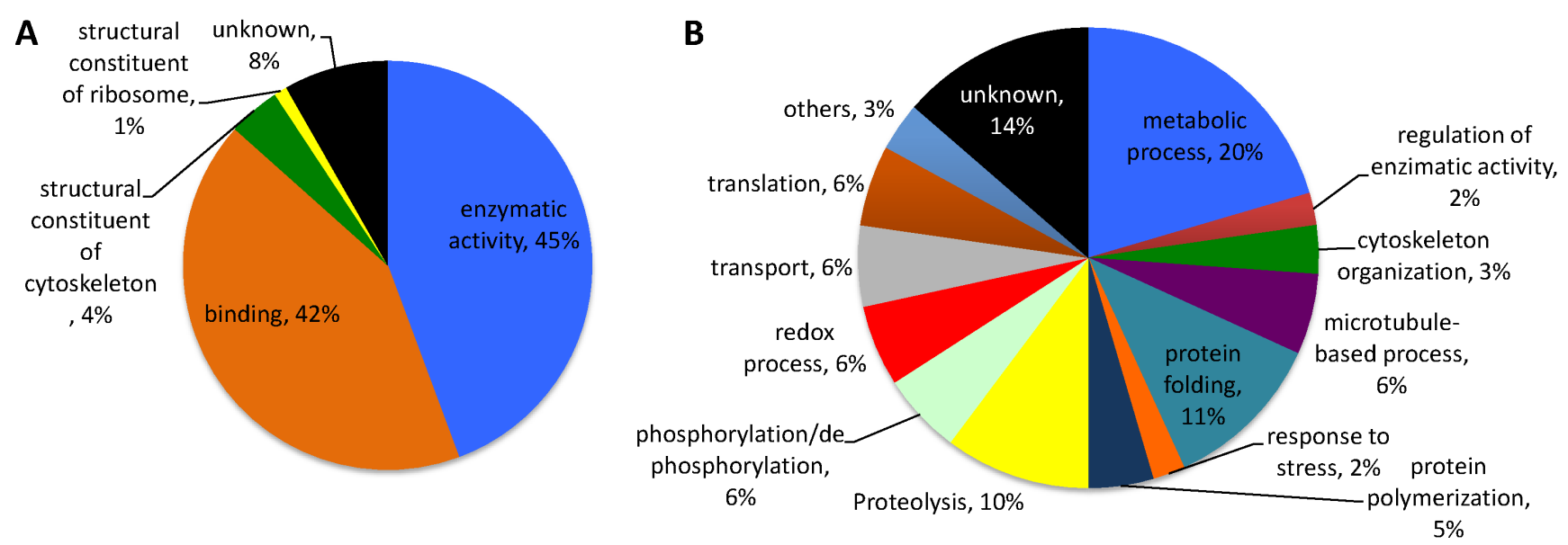

D

phosphorylation/
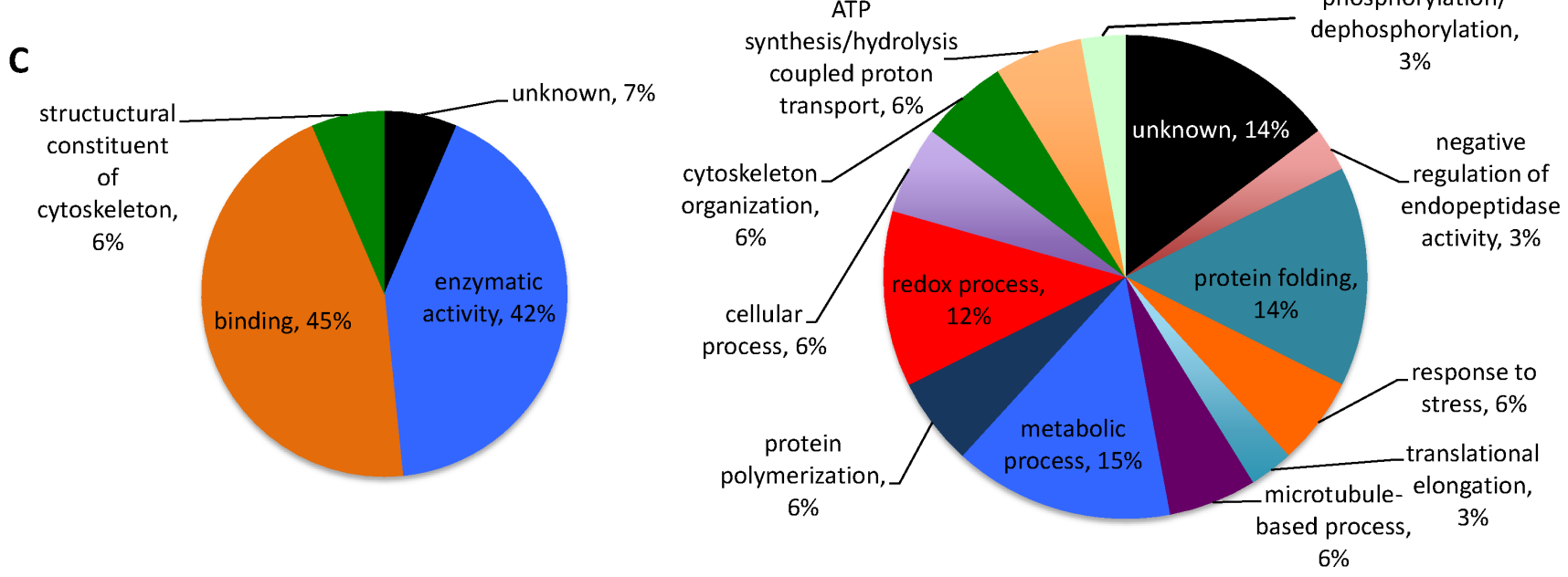

Figure 6: Gene ontology for Rhipicephalus tick proteins recognized by IgE in patient 1 and control sera and by anti$\boldsymbol{\alpha}$-Gal IgE antibodies. The $R$. microplus BME/CTVM23 tick cell proteins identified by proteomics analysis were functionally annotated for molecular function and biological process. A. Molecular function for unique proteins identified by patient and control sera. B. Biological process for unique proteins identified by patient and control sera. C. Molecular function for proteins recognized by anti- $\alpha$-Gal antibodies. D. Biological process for proteins recognized by anti- $\alpha-G a l$ antibodies. 


\section{DISCUSSION}

The objective of this study was to identify and characterize tick proteins potentially associated with anaphylaxis to tick bite. To address this objective, a comparative proteomics approach was used to characterize the IgE antibody response against tick proteins and $\alpha$-Gal in a healthy individual and patients with anaphylactic reaction to tick bite but without delayed anaphylaxis to mammalian red meat. Salivary gland proteins from the same tick species to which patients reacted, $R$. bursa and $H$. marginatum, and $R$. microplus BME/CTVM23 tick cell proteins were used for serological, Western blot, and proteomics analyses. Cultured tick cells are models to study tick-host-pathogen interactions [25, 26], and R. microplus is the Rhipicephalus species with the best genome sequence coverage that facilitates protein assignment after MS analysis [27]. Therefore, protein extracts from the $R$. microplus BME/CTVM23
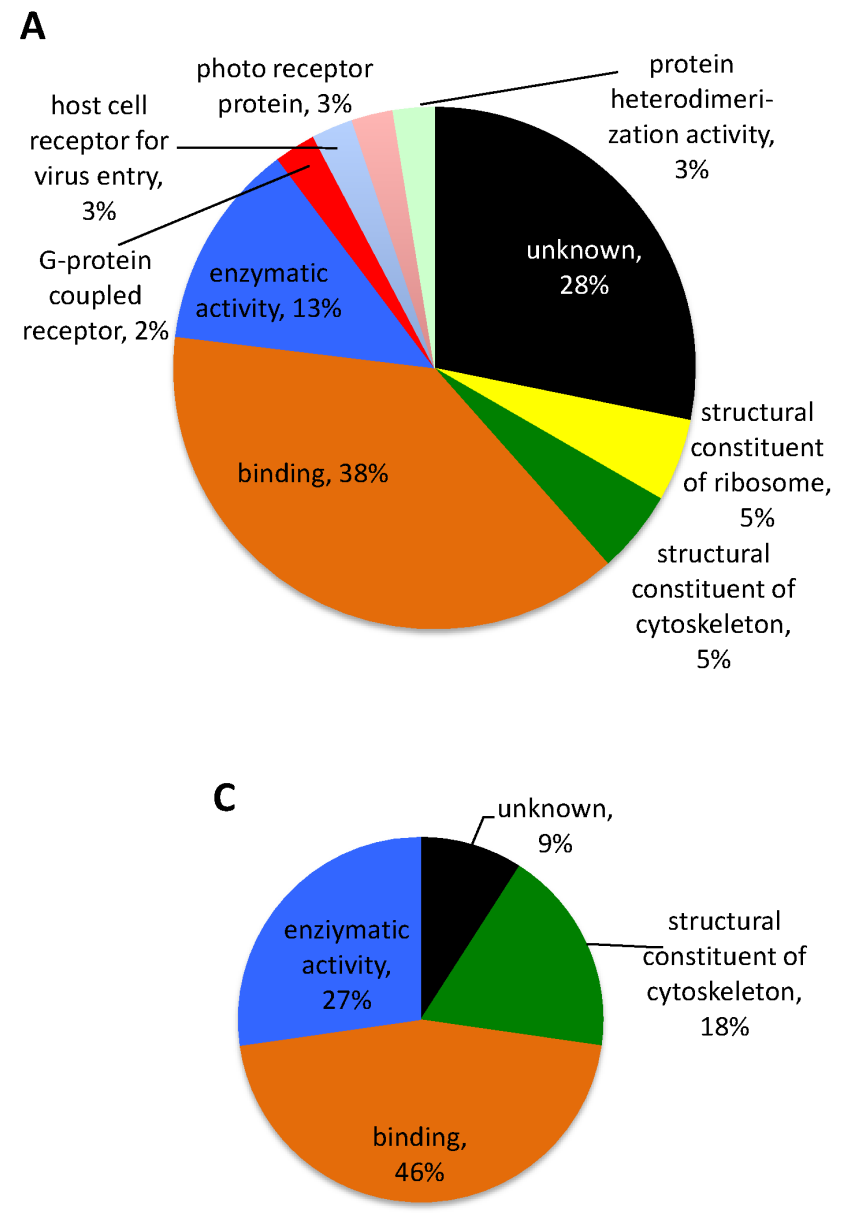

tick cell line were used for the identification of proteins differentially recognized by patient 1 , who developed anaphylaxis to $R$. bursa tick bite.

These results supported a patient-specific IgE antibody response to tick species responsible for the reported anaphylactic reaction to tick bite, and suggested the possible implication of anti- $\alpha-G a l$ IgE response in patient 1 , but not in patient 2 . Both patients and the healthy individual serologically recognized tick proteins with and without $\alpha$-Gal modifications. Although protein samples were obtained from different tissues (salivary glands from partially fed female ticks and tick cell culture), which explains differences in protein identification, similar molecular functions and biological processes were identified for the tick proteins recognized by patients and control sera. The tick proteins recognized by patient and control sera are probably involved in tick feeding in humans, which supports a role for the enzymatic activity and binding molecular functions and protein processing
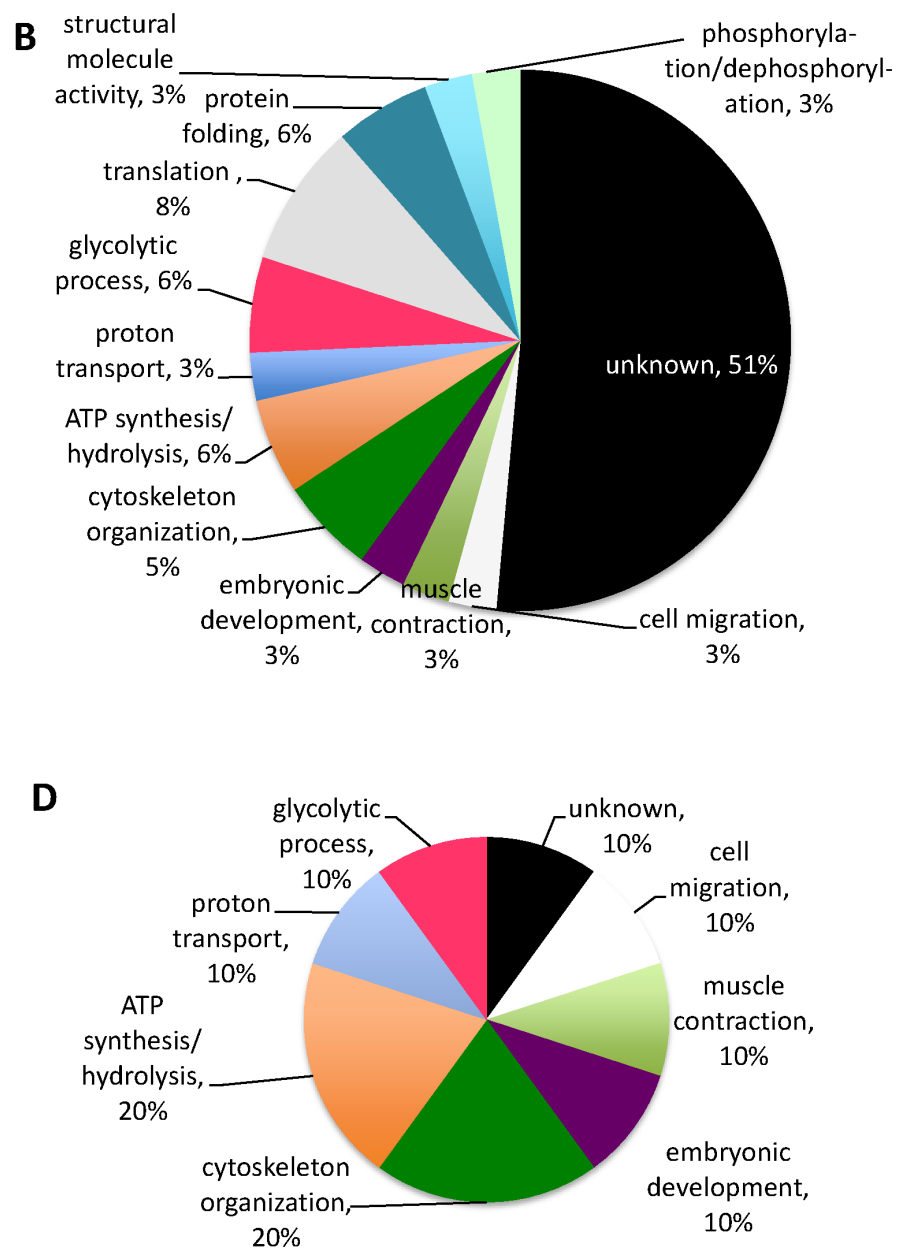

Figure 7: Gene ontology for Hyalomma tick proteins recognized by IgE in patient 2 and control sera and by anti- $\alpha$-Gal IgE antibodies. The H. marginatum salivary gland proteins identified by proteomics analysis were functionally annotated for molecular function and biological process. A. Molecular function for unique proteins identified by patient and control sera. B. Biological process for unique proteins identified by patient and control sera. C. Molecular function for proteins recognized by anti- $\alpha$-Gal antibodies. D. Biological process for proteins recognized by anti- $\alpha-$ Gal antibodies. 
biological process in the successful tick feeding on humans $[4,28]$.

Some of the proteins identified as differentially recognized by patients sera were predicted as localized intracellular. However, orthologs for these proteins were found in the sialome reported in other tick species. Previous reports have shown the presence in the tick sialome of otherwise predicted intracellular proteins, suggesting the activity of non-classical secretion mechanisms such as exosome secretion in tick salivary glands [29]. Therefore, these results probably reflected the IgE antibody response to salivary proteins secreted during tick feeding.

As previously reported in A. americanum $[12,19]$, I. ricinus [30] and $H$. longicornis [16], anti- $\alpha-G a l$ IgE antibodies recognized proteins with this modification in $R$. bursa and $H$. marginatum salivary glands, and $R$. microplus BME/CTVM23 tick cells, showing for the first time the presence of $\alpha$-Gal-modified proteins in Rhipicephalus and Hyalomma tick species. These results also confirmed previous findings in H. longicornis [16], supporting the presence of $\alpha$-Gal-modified proteins in the sialome of $H$. marginatum.

Recently, we proposed that tick-host-pathogen interactions evolved with conflict and cooperation between parties [31]. The conflict between ticks and hosts includes host local and systemic reactions to tick bite [31]. The comparative proteomics analysis showed the presence of tick proteins that react with $\mathrm{IgE}$ in patients but not control sera. The results reported here in Rhipicephalus and $H$. marginatum and in other tick species suggested a relationship between tick sialome proteins and the development of anaphylactic reactions to tick bite [7-10, $12,16,30]$. However, the human immune response to tick bite could have different outcomes [20]. Obviously, many individuals do not develop anaphylactic reactions to tick bite, probably because the immune system is able to produce $\operatorname{IgM}$ and $\operatorname{IgG}$ responses that have a protective role as opposed to the IgE response [15, 32]. In fact, differences in tick proteins recognized by patients and healthy individual sera may reflect differences in the immune response that affect the development of anaphylaxis. However, in a growing number of cases tick bite results in the development of delayed anaphylaxis to red meat consumption, which has been associated with the IgE response to $\alpha$-Gal [12-20]. Therefore, tick proteins with putative $\alpha$-Gal modifications and recognized by patients and control sera may be responsible for sensitization to $\alpha$-Gal with risk of developing allergy to read meat consumption. At least in some cases, patients with anaphylaxis to tick bite may be at a higher risk of developing allergy to red meat consumption. Finally, as shown here for patient 1 , some individuals may react to tick bite with an immediate anaphylaxis that could be also related to anti- $\alpha$-Gal IgE response, which may increase susceptibility to tick bite [20]. These results also suggested that both immediate anaphylaxis to tick bite and delayed anaphylaxis to red meat consumption might eventually concur in some patients with still unknown differences associated to host immune response, tick species and susceptibility to tick-borne pathogens [15, 20, 23]. Other factors such as tick removal [23] and food-dependent exercise-induced anaphylaxis (FDEIA) [20, 33, 34] may also affect the development of anaphylactic reactions to tick bite. Consequently, additional research is needed to understand the mechanisms by which ticks alter host immune response resulting in immediate anaphylaxis to tick bite and/or delayed anaphylaxis to red meat consumption.

Recently, we proposed that tick proteins reactive with sera of patients with anaphylactic reactions to tick bite and red meat consumption could be used for diagnosis, treatment and prevention of these emerging tick-borne allergies [15]. Tick proteins putatively present in the sialome and reacting with $\operatorname{IgE}$ in patients but not control sera could be used for the diagnosis of a predisposing condition for anaphylaxis to tick bite, particularly when highly conserved across different tick species. Furthermore, tick antigens inducing a protective immune response could be used to develop vaccines for the control of tick infestations, transmission of tickborne pathogens and anaphylaxis to tick bite or red meat consumption [15, 32, 35]. Therefore, sialome proteins with $\alpha$-Gal modification and recognized by patients but not control sera could be selected as candidate protective antigens for the treatment and prevention of tick-borne anaphylactic reactions and other tick-borne diseases.

\section{MATERIALS AND METHODS}

\section{Patients and the healthy individual}

The use of human peripheral blood serum samples from patients and the healthy individual was done with their informed consent in compliance with the Helsinki Declaration. Nursing personnel at the Hospital Virgen del Valle (Toledo) and the General University Hospital of Ciudad Real, Spain, extracted blood samples.

The first patient (patient 1) was a 55 year-old male with repeated anaphylactic reactions to $R$. bursa tick bites. The patient was working in a goat farm in Toledo Province, Castilla-La Mancha, Spain. About 15 years ago the patient was diagnosed with allergies to cereal flours and leguminous vegetables used for goat feeding and prescribed with corticoids and bronchodilators. Recently, he suffered two episodes of anaphylaxis after $R$. bursa tick bites on different parts of the body that resulted in generalized itching (Figures $1 \mathrm{~A}$ and 1B), difficult breathing, nausea and somnolence that required medical attention. The patient described the occurrence of previous 
tick bites without symptoms. Blood samples used in this study were collected after the second anaphylaxis to tick bite.

The second patient (patient 2) was a 52 yearold male without previous record of allergic reactions. He showed generalized itching and erythema, difficult breathing, nausea and somnolence that appeared during his work at a cattle farm in Ciudad Real Province, CastillaLa Mancha, Spain, and required medical attention. This patient was diagnosed with anaphylaxis likely due to $H$. marginatum tick bites [36].

The unrelated healthy control individual was a 55 year-old male with record of tick bites, which had not resulted in any allergic reactions. Both patients and the healthy individual were red meat tolerant.

\section{Serum sample preparation}

For separation of serum from total blood, a sterile tube without anticoagulant was used. The blood from each patient and the healthy individual was maintained in standing position at room temperature (RT) for clotting (20-30 $\mathrm{min}$ ), and centrifuged at $1,500 \mathrm{x}$ g for $20 \mathrm{~min}$ at RT. Serum was collected and conserved at $-20{ }^{\circ} \mathrm{C}$ until used for analysis.

\section{Tick collection and protein sample preparation}

Unfed $R$. bursa female ticks $(N=7)$ were collected in June 2014 in an area near the goat farm where the patient 1 works (Hontanar, Toledo, Spain; 39.59N-4.50E). Ticks were collected by dragging the vegetation with a $2 \times 1 \mathrm{~m}$ white cotton flannelette [37], stored refrigerated and quickly transported to the laboratory where they were identified [38], and stored at $-20{ }^{\circ} \mathrm{C}$ until processed. Partially fed $H$. marginatum female ticks $(N=10)$ were collected at initial stages of feeding from cattle in May 2001 in Son Parc (Menorca, Spain; 40.02N-4.09E), and stored in $70 \%$ ethanol until processed. The ticks were then washed with phosphate buffered saline (PBS), dissected and the salivary glands were stored separately in RNAlater (Invitrogen, Carlsbad, CA, USA) and used for protein extraction. For protein extraction, salivary glands were homogenized with a glass homogenizer (20 strokes) in lysis buffer (7M Urea, 2M Thiourea, $2 \% \quad 3$ - [(3-cholamidopropyl)dimethylammonio]1-propanesulfonate, CHAPS) supplemented with complete mini protease inhibitor cocktail (Roche, Basel, Switzerland). Sample was sonicated for $1 \mathrm{~min}$ in an ultrasonic cooled bath followed by $10 \mathrm{sec}$ vortex. After 3 cycles of sonication-vortex, the homogenate was centrifuged at $200 \times \mathrm{g}$ for $5 \mathrm{~min}$ at $4{ }^{\circ} \mathrm{C}$ to remove cellular debris. The supernatant was collected and protein concentration was determined using the Bradford Protein Assay (Thermo Scientific, San Jose, CA, USA) with BSA as standard.

\section{Cultured tick cells and protein sample preparation}

The tick cell line BME/CTVM23, derived from $R$. microplus embryos (provided by L. Bell-Sakyi, the Tick Cell Biobank, The Pirbright Institute, UK), was cultured in L15 medium as described previously [25]. Approximately $10^{7}$ cells were centrifuged at $1,000 \times \mathrm{g}$ for $3 \mathrm{~min}$, washed 3 times with PBS and homogenized in lysis buffer following the same protocol described above for the extraction of tick salivary gland proteins.

\section{Skin tests}

Skin prick tests were conducted to a panel of commercially available food allergens (beef, pork, horse, lamb, rabbit, ostrich meats and bovine serum albumin; Bial-Aristegui Laboratory, Bilbao, Spain). Cetuximab, a monoclonal antibody presenting the $\alpha$-Gal oligosaccharide in the heavy chain and used for the treatment of metastatic colorectal cancer $[18,39]$, was used in skin tests for diagnosis of $\alpha$-Gal-induced anaphylaxis [40]. The prick test to cetuximab (Erbitux; Merck SL, Madrid, Spain) was conducted at a concentration of $5 \mathrm{mg} / \mathrm{ml}$ and intradermal tests to cetuximab were conducted with $50 \mu \mathrm{l}$ of $1: 10(0.5$ $\mathrm{mg} / \mathrm{ml}), 1: 100(0.05 \mathrm{mg} / \mathrm{ml})$ and 1:1000 $(0.005 \mathrm{mg} / \mathrm{ml})$ dilutions as described previously [40]. Histamine prick was used as positive skin test control.

\section{Determination of anti-allergens IgE antibody titers}

The ImmunoCAP-250 analyzer (Phadia, Uppsala, Sweden) was used to determine the IgE levels to commercial allergens (pork, lamb, rabbit, beef and bovine serum albumin) following manufacturer instructions.

\section{Determination of anti-tick proteins IgG, IgM and IgE antibody titers}

The ELISA tests to determine the $\operatorname{IgG}, \operatorname{IgE}$ and IgM content in response to tick proteins in patients and control sera were performed using $R$. bursa and $H$. marginatum salivary glands, and $R$. microplus BME/ CTVM23 cell proteins. Plates were coated with $100 \mathrm{ng}$ proteins per well in carbonate/bicarbonate buffer and incubated overnight at $4{ }^{\circ} \mathrm{C}$. Following five washes with PBS containing $0.05 \%$ Tween 20 (PBST), patients and control sera were added at 1:50 dilution in PBS and incubated for $1 \mathrm{~h}$ at $37^{\circ} \mathrm{C}$ followed by five washes with PBST. For the detection of immunoglobulin, 100 $\mu$ of goat anti-human immunoglobulins-peroxidase IgG (FC specific), IgM ( $\mu$-chain specific), and $\operatorname{IgE}(\varepsilon$-chain specific) (Sigma-Aldrich, Madrid, Spain) were added at 
1:1000 dilution in blocking buffer ( $1 \%$ HSA in phosphate buffered saline, PBS supplemented with $0.05 \%$ Tween 20 ) (Sigma-Aldrich, Madrid, Spain) (100 $\mu \mathrm{l} /$ well). The plates were then incubated for $1 \mathrm{~h}$ at $37^{\circ} \mathrm{C}$ and subsequently washed five times with PBST. Reaction was visualized by adding $100 \mu \mathrm{l}$ of 3,3,'5,5-tetramethylbenzidine (Promega, Madison, WI, USA) and incubated for $20 \mathrm{~min}$ in the dark at RT. The optical density (OD) was measured at $450 \mathrm{~nm}$ with an ELISA reader. The average value of the blanks (wells without tick proteins coating; $N=4$ ) was subtracted from all reads and the average of 4 replicates for each sample was used for analysis.

\section{Determination of anti- $\alpha-G a l$ IgG, IgM and IgE antibody titers}

The anti- $\alpha-\mathrm{Gal}$ and total $\mathrm{IgE}$ antibody content was determined in patients and control sera using the ImmunoCAP Phadia 250 automated platform (Thermo Fisher Scientific, Uppsala, Sweden) with the commercial kits ImmunoCap $\alpha$-Gal bovine Thyroglobulin and ImmunoCap Total IgE, respectively, according to the manufacturer's instructions. Levels higher than 100 and $0.35 \mathrm{kU} / 1$ were considered positive for total $\mathrm{IgE}$ and anti$\alpha-$ Gal IgE levels, respectively. Anti- $\alpha-G a l$ IgG, IgM and $\mathrm{IgE}$ antibody titers were determined in serum samples from patients and the control healthy individual. ELISA plates were coated with $100 \mu \mathrm{l} /$ well (100 ng) of Gal1-3Gal $\beta 1$ 4GlcNAc-Human serum albumin (HSA) (Carbosynth Ltd, Berkshire, UK) in carbonate/bicarbonate buffer and incubated overnight at $4{ }^{\circ} \mathrm{C}$. Then, $100 \mu \mathrm{l}$ of blocking buffer (Sigma-Aldrich) were added to each well and incubated $1 \mathrm{hr}$ at RT followed by five washes with PBST. The sera were added to plates at 1:50 dilution in blocking buffer and incubated for $1 \mathrm{hr}$ at $37^{\circ} \mathrm{C}$, followed by five washes with PBST. Goat anti-human immunoglobulinsperoxidase $\operatorname{IgG}$ (FC specific), IgM ( $\mu$-chain specific), or $\operatorname{IgE}(\varepsilon$-chain specific) (Sigma-Aldrich) were added at 1:1000 dilution in blocking buffer $(100 \mu \mathrm{l} /$ well $)$, and plates incubated for $1 \mathrm{hr}$ at RT. Plates were then washed five times with PBST, and color developed by the addition of $100 \mu \mathrm{l}$ of 3,3,'5,5-tetramethylbenzidine (Promega) and protected from the light for $20 \mathrm{~min}$ at RT. Reactions were stopped with the addition of $50 \mu \mathrm{l}$ sulfuric acid, and the OD were measured at $450 \mathrm{~nm}$ with an ELISA reader. The average value of the blanks (wells without Gal $\alpha 1-3 \mathrm{Gal} \beta 1$ 4GlcNAc-HSA coating; $N=4$ ) was subtracted from all reads and the average of 4 replicates for each sample was used for analysis.

\section{Western blot analyses}

1-D Western blot. Twenty $\mu \mathrm{g}$ of $R$. bursa or $H$. marginatum salivary gland and $R$. microplus BME/
CTVM23 cell protein extracts were methanol/chloroform precipitated, resuspended in Laemmli sample buffer and separated on a $12 \%$ sodium dodecyl sulfate (SDS) polyacrylamide gel under reducing conditions. After electrophoresis, proteins were transferred to nitrocellulose membranes (Bio-Rad, Hercules, CA, USA), blocked with 1\% BSA (Sigma) in Tris-buffered saline (TBS; $50 \mathrm{mM}$ Tris-Cl, $\mathrm{pH} 7.5,150 \mathrm{mM} \mathrm{NaCl}$ ) and incubated overnight at $4{ }^{\circ} \mathrm{C}$ with patient serum (dilution $1: 200$ ). To detect the $\mathrm{IgE}$ antibodies bound to tick proteins, membranes were incubated with goat anti-human IgE conjugated peroxidase (dilution 1:1000; Sigma). Immunoreactive proteins were visualized with TMB (Promega).

2-D Western blot. Two hundred $\mu \mathrm{g}$ of $H$. marginatum salivary gland or $R$. microplus BME/CTVM23 tick cell proteins were precipitated with chloroform/methanol, resuspended in $500 \mu$ l of DeStreak Rehydration Solution ${ }^{\mathrm{TM}}$ (GE Healthcare) supplemented with $0.5 \%$ of IPG buffer 3-11NL pH range (GE Healthcare) and loaded onto IPG strips (pH 3-11NL Drystrip $7 \mathrm{~cm}$; GE Healthcare). Isoelectrofocusing was performed at $20{ }^{\circ} \mathrm{C}$ using an Ettan IPGphor 3 (GE Healtcare) with the following conditions: $30 \mathrm{~V}$ for $3 \mathrm{hrs}, 60 \mathrm{~V}$ for $3 \mathrm{hrs}, 60-300 \mathrm{~V}$ for $30 \mathrm{~min}, 300 \mathrm{~V}$ for $30 \mathrm{~min}, 300-1000 \mathrm{~V}$ for $1 \mathrm{hr}, 1000 \mathrm{~V}$ for $1 \mathrm{hr}, 1000-5000 \mathrm{~V}$ for $5 \mathrm{hr}, 5000 \mathrm{~V}$ for $5 \mathrm{hr}$. Prior to second dimension, proteins present in focused IPG strips were reduced and alkylated by successive incubations in two different equilibration buffer solutions $(50 \mathrm{mM}$ Tris- $\mathrm{HCl} \mathrm{pH} \mathrm{8.8,} 6 \mathrm{M}$ urea, 30\% v/v glycerol, 2\% w/v SDS, $0.2 \%$ bromophenol blue, supplemented with either $0.5 \% \mathrm{w} / \mathrm{v}$ dithiothreitol (DTT) for the first incubation or $4.5 \% \mathrm{w} / \mathrm{v}$ iodoacetamide for the second incubation) for 15 min each with gentle rocking. Equilibrated IPG strips were placed onto homogeneous $12 \%$ SDS polyacrylamide gels and electrophoresis was carried out for $1 \mathrm{~h}$ at $120 \mathrm{~V}$. Four 2D gels were performed simultaneously, one was stained with SYPRO ${ }^{\circledR}$ Ruby Protein Gel Stain (Thermo Scientific) and the others were transferred to nitrocellulose membranes to perform Western blots with patients and control sera, following the same protocol described above for 1D Western blot. To detect tick proteins with $\alpha$-Gal, membranes were blocked with 1\% HSA (Sigma) in TBS, incubated overnight at $4^{\circ} \mathrm{C}$ with anti- $\alpha$-Gal epitope $\operatorname{IgM}$ antibody (Enzo Life Sciences) diluted 1:5 in TBS, and then incubated with anti-mouse IgM conjugated with peroxidase (dilution 1:2000; Sigma). The tick protein spots recognized by patient or control sera and by anti$\alpha$-Gal antibodies were manually excised from the stained gel, dehydrated with acetonitrile and vacuum-dried in a speed vacuum centrifuge until proteomics analysis.

\section{Proteomics analysis}

Dried spots were re-hydrated and digested overnight at $37{ }^{\circ} \mathrm{C}$ with $12.5 \mathrm{ng} / \mu \mathrm{l}$ trypsin (Promega, Madison, WI, 
USA) in $50 \mathrm{mM}$ ammonium bicarbonate, $\mathrm{pH} 8.8$ [41]. Trifluoroacetic acid was added to a final concentration of $1 \%$ and the peptides were finally desalted onto OMIX Pipette tips C 18 (Agilent Technologies, Santa Clara, CA, USA), dried-down and stored at $-20^{\circ} \mathrm{C}$ until used for mass spectrometry (MS) analysis. The desalted protein digests were resuspended in $0.1 \%$ formic acid and analyzed by reversed phase (RP) liquid chromatography (LC) coupled to mass spectrometry (RP-LC-MS/MS) using an Easy-nLC II system coupled to an ion trap LTQ-Orbitrap-Velos-Pro mass spectrometer (Thermo Scientific). The peptides were concentrated on-line by reverse phase chromatography using a $0.1 \mathrm{~mm} \times 20 \mathrm{~mm} \mathrm{C18} \mathrm{RP} \mathrm{precolumn} \mathrm{(Thermo}$ Scientific), and separated using a $0.075 \mathrm{~mm} \times 100 \mathrm{~mm}$ C18 RP column (Thermo Scientific) operating at $0.3 \mu \mathrm{l} /$ min. Peptides were eluted using a 60 min gradient from $5 \%$ to $40 \%$ solvent $\mathrm{B}$ in solvent $\mathrm{A}$ (solvent $\mathrm{A}: 0.1 \%$ formic acid in water, solvent B: $0.1 \%$ formic acid, $80 \%$ acetonitrile in water). Electrospray ionization (ESI) was carried out using a nano-bore emitters stainless steel ID 30 $\mu \mathrm{m}$ (Thermo Scientific) interface. Peptides were detected in survey scans from 400 to 1600 atomic mass units (amu, $1 \mu \mathrm{scan}$ ), followed by fifteen data-dependent MS/ MS scans (Top 15), using an isolation width of 2 massto-charge ratio units, normalized collision energy of $35 \%$, and dynamic exclusion applied during $30 \mathrm{sec}$ periods.

Peptide identification from the MS/MS raw data was carried out using the SEQUEST algorithm (Proteome Discoverer 1.4; Thermo Scientific). Database search was performed against the Rhipicephalus or Hyalomma (12,465 and 5709 entries in November 2015, respectively) Uniprot protein databases. The following constraints were used for the searches: tryptic cleavage after Arg and Lys, up to two missed cleavage sites, and tolerances of 10 ppm for precursor ions and 0.8 Da for MS/MS fragment ions, and the searches were performed allowing optional methionine oxidation and cysteine carbamidomethylation. Searches were performed against a decoy database in an integrated decoy approach. A false discovery rate $(\mathrm{FDR})<$ 0.01 was considered as a condition for successful peptide assignments and at least 2 peptides per protein was the condition for successful protein identification (Supporting information Data Set 1). Functional annotations for identified proteins were assigned using the Blast2GO software (version 3; http://www.blast2go.org/), manually revised and included gene ontology (GO) annotations for biological process, molecular function and cellular component (Supporting information Data Set 1).

\section{ACKNOWLEDGMENTS}

We thank A. Marina and E. Morato (Protein Chemistry Facility, CBMSO, Spain) for technical assistance, and L. Bell-Sakyi (the Tick Cell Biobank, The Pirbright Institute, UK) for providing the $R$. microplus tick cell line BME/CTVM23.

\section{CONFLICTS OF INTEREST}

The authors declare no commercial or financial conflict of interest.

\section{FUNDING}

Part of this research was supported by the European Union FP7 ANTIGONE project number 278976. L.M-H was supported by the University of Castilla La Mancha (UCLM, Spain) fellowship. M.V and I.G.FM were supported by the Research Plan of UCLM. F.R-F was supported by the 'Ramón y Cajal' program of the Spanish Ministry of Economy and Competitiveness.

\section{REFERENCES}

1. de la Fuente J, Estrada-Peña A, Venzal JM, Kocan KM, Sonenshine DE. Overview: Ticks as vectors of pathogens that cause disease in humans and animals. Front Biosci. 2008; 13: 6938-6946.

2. Jones KE, Patel NG, Levy MA, Storeygard A, Balk D, Gittleman JL, Daszak P. Global trends in emerging infectious diseases. Nature. 2008; 451:990-994.

3. Estrada-Peña A, Ostfeld RS, Peterson AT, Poulin R, de la Fuente J. Effects of environmental change on zoonotic disease risk: an ecological primer. Trends Parasitol. 2014; 30: 205-214.

4. Preston SG, Majtán J, Kouremenou C, Rysnik O, Burger LF, Cabezas Cruz A, Chiong Guzman M, Nunn MA, Paesen GC, Nuttall PA, Austyn JM. Novel immunomodulators from hard ticks selectively reprogramme human dendritic cell responses. PLoS Pathog. 2013; 9: e1003450.

5. Severo MS, Pedra JHF, Ayllón N, Kocan KM, de la Fuente J. Anaplasma. In Tang, YW, Sussman M, Liu D, Poxton I, and Schwartzman J. (Eds.) Molecular Medical Microbiology (2nd edition). Academic Press, Elsevier, Cambridge 2015; 2033-2042.

6. McKay WJ. Tick bite and allergy. Med J Aust. 1940; 1: 458-459.

7. McGain F, Welton R, Solley GO, Winkel KD. First fatalities from tick bite anaphylaxis. J Allergy Clin Immunol Pract. 2016; 4: 769-770.

8. Van Wye J, Hsu YP, Terr AI, Moss RB. Anaphylaxis from a tick bite. N Engl J Med. 1991; 324: 777-778.

9. Hilger C, Kuehn A, Raulf M, Jakob T. Cockroach, tick, storage mite and other arthropod allergies: Where do we stand with molecular allergy diagnostics? Part 15 of the Series Molecular Allergology. Allergo J Int. 2014; 23: 172178.

10. Rappo TB, Cottee AM, Ratchford AM, Burns BJ. Tick bite anaphylaxis: incidence and management in an Australian emergency department. Emerg Med Australas. 2013; 25: 297-301. 
11. van Nunen SA, O'Connor KS, Fernando SL, Clarke LR, Boyle RX. An association between Ixodes holocyclus tick bite reactions and red meat allergy. Int Med. 2007; 37(Suppl 5): A132.

12. Commins SP, James HR, Kelly LA, Pochan SL, Workman LJ, Perzanowski MS, Kocan KM, Fahy JV, Nganga LW, Ronmark E, Cooper PJ, Platts-Mills TA. The relevance of tick bites to the production of $\operatorname{IgE}$ antibodies to the mammalian oligosaccharide galactose- $\alpha$-1,3-galactose. J Allergy Clin Immunol. 2011; 127: 1286-1293.

13. Commins SP, Platts-Mills TA. Delayed anaphylaxis to red meat in patients with IgE specific for galactose alpha-1,3galactose (alpha-gal). Curr Allergy Asthma Rep. 2013; 13: 72-77.

14. Nuñez R, Carballada F, Gonzalez-Quintela A, Gomez-Rial J, Boquete M, Vidal C. Delayed mammalian meat-induced anaphylaxis due to galactose- $\alpha$-1,3-galactose in 5 European patients. J Allergy Clin Immunol. 2011; 128: 1122-1124.

15. Cabezas-Cruz A, Mateos-Hernández L, Pérez-Cruz M, Valdés JJ, Mera IG, Villar M, de la Fuente J. Regulation of the immune response to $\alpha$-Gal and vector-borne diseases. Trends Parasitol. 2015; 31: 470-476.

16. Chinuki Y, Ishiwata K, Yamaji K, Takahashi H, Morita E. Haemaphysalis longicornis tick bites are a possible cause of red meat allergy in Japan. Allergy 2015; 71: 421-425.

17. van Nunen SA, O'Connor KS, Clarke LR, Boyle RX, Fernando SL. An association between tick bite reactions and red meat allergy in humans. Med J Aust. 2009; 190: 510-511.

18. Chung CH, Mirakhur B, Chan E, Le QT, Berlin J, Morse M, Murphy BA, Satinover SM, Hosen J, Mauro D, Slebos RJ, Zhou Q, Gold D, et al. Cetuximab-induced anaphylaxis and IgE specific for galactose-alpha-1,3-galactose. N Engl J Med. 2008; 358: 1109-1117.

19. Adams CB, Street DS, Crass M, Bossaer JB. Low rate of cetuximab hypersensitivity reactions in Northeast Tennessee: An Appalachian effect? J Oncol Pharm Pract. 2016; 22: 784-789.

20. Fischer J, Yazdi AS, Biedermann T. Clinical spectrum of $\alpha$-Gal syndrome: from immediate-type to delayed immediate-type reactions to mammalian innards and meat. Allergo J Int. 2016; 25: 55-62.

21. Galili U. The alpha-gal epitope and the anti-Gal antibody in xenotransplantation and in cancer immunotherapy. Immunol Cell Biol. 2005; 83: 674-686.

22. Galili U. Anti-Gal: an abundant human natural antibody of multiple pathogeneses and clinical benefits. Immunol. 2013; 140: 1-11.

23. van Nunen S. Tick-induced allergies: mammalian meat allergy, tick anaphylaxis and their significance. Asia Pac Allergy 2015; 5: 3-16.

24. Brown FT, Hamilton DL. Tick bite anaphylaxis in Australia. J Accid Emerg Med. 1998; 15: 111-113.

25. Alberdi MP, Nijhof AM, Jongejan F, Bell-Sakyi L. Tick cell culture isolation and growth of Rickettsia raoultii from Dutch Dermacentor reticulatus ticks. Ticks Tick-Borne Dis. 2012; 3: 349-354.

26. Villar M, Ayllón N, Alberdi P, Moreno A, Moreno M, Tobes R, Mateos-Hernández L, Weisheit S, Bell-Sakyi L, de la Fuente J. Integrated metabolomics, transcriptomics and proteomics identifies metabolic pathways affected by Anaplasma phagocytophilum infection in tick cells. Mol Cell Proteomics 2015; 14: 3154-3172.

27. Bellgard MI, Moolhuijzen PM, Guerrero FD, Schibeci D, Rodriguez-Valle M, Peterson DG, Dowd SE, Barrero R, Hunter A, Miller RJ, Lew-Tabor AE. Cattle TickBase: an integrated internet-based bioinformatics resource for Rhipicephalus (Boophilus) microplus. Int J Parasitol. 2012; 42: 161-169.

28. Chmelař J, Kotál J, Karim S, Kopacek P, Francischetti IM, Pedra JH, Kotsyfakis M. Sialomes and mialomes: a systems-biology view of tick tissues and tick-host interactions. Trends Parasitol. 2016; 32: 242-254.

29. Díaz-Martín V, Manzano-Román R, Valero L, Oleaga A, Encinas-Grandes A, Pérez-Sánchez R. An insight into the proteome of the saliva of the argasid tick Ornithodoros moubata reveals important differences in saliva protein composition between the sexes. J. Proteomics. 2013; 80: 216-235.

30. Hamsten C, Starkhammar M, Tran TA, Johansson M, Bengtsson U, Ahlén G, Sällberg M, Grönlund $H$, van Hage M. Identification of galactose- $\alpha-1,3$-galactose in the gastrointestinal tract of the tick Ixodes ricinus; possible relationship with red meat allergy. Allergy. 2013; 68: 549552.

31. de la Fuente J, Villar M, Cabezas-Cruz A, Estrada-Peña A, Ayllón N, Alberdi P. Tick-host-pathogen interactions: conflict and cooperation. PLoS Pathog. 2016; 12: e1005488.

32. Cabezas-Cruz A, Valdés JJ, de la Fuente J. Control of vector-borne infectious diseases by human immunity against $\alpha$-Gal. Exp Rev Vaccines. 2016; 15: 953-955.

33. Morisset M, Richard C, Astier C, Jacquenet S, Croizier A, Beaudouin E, Cordebar V, Morel-Codreanu F, Petit N, Moneret-Vautrin DA, Kanny G. Anaphylaxis to pork kidney is related to IgE antibodies specific for galactosealpha-1,3-galactose. Allergy. 2012; 67: 699-704.

34. Fischer J, Hebsaker J, Caponetto P, Platts-Mills TA, Biedermann T. Galactose-alpha-1,3-galactose sensitization is a prerequisite for pork-kidney allergy and cofactor-related mammalian meat anaphylaxis. J Allergy Clin Immunol. 2014; 134: 755-759.

35. de la Fuente J, Contreras M. Tick vaccines: current status and future directions. Exp Rev Vaccines. 2015; 14: 13671376.

36. García Rodríguez C, Alfaya Arias T. Anafilaxia en un ganadero. Alergia a picadura de garrapata (Hyalomma marginatum). Sesiones Interhospitalarias 2014; 2013-2014: 173-177. http://www.sesionesinterhospitalarias-smclm. 
com/complejociudadreal/anafilaxiapicaduragarrapata.pdf

37. Ginsberg HS, Ewing CP. Comparison of flagging, walking, trapping, and collecting ticks from hosts as sampling methods for northern deer ticks, Ixodes dammini, and lone star ticks, Amblyomma americanum (Acari: Ixodidae). Exp Appl Acarol. 1989; 7: 313-322.

38. Manilla G. Fauna d'ltalia. Acari: Ixodida. Edizioni Calderini, Bologna, Italy, 1998.

39. Cabezas-Cruz A, Valdés J, de la Fuente J. Cancer research meets tick vectors for infectious diseases. Lancet Infect Dis. 2014; 10: 916-917.
40. Jacqueret S, Moneret-Vautrin DA, Bihain BE. Mammalian meat-induced anaphylaxis: Clinical relevance of antigalactose- $\alpha$-1,3-galactose IgE confirmed by means of skin tests to cetuximab. J Allergy Clin Immunol. 2009; 124: 603605.

41. Shevchenko A, Tomas H, Havlis J, Olsen JV, Mann M. In-gel digestion for mass spectrometric characterization of proteins and proteomes. Nat Protoc. 2006; 1: 2856-2860. 